\title{
Relations between Psychological Status and Eye Movements
}

\author{
Kohei Arai \\ Graduate School of Science and Engineering \\ Saga University \\ Saga City, Japan
}

\begin{abstract}
Relations between psychological status and eye movements are found through experiments with readings of different types of documents as well as playing games. Psychological status can be monitored with Electroencephalogram: EEG sensor while eye movements can be monitored with Near Infrared: NIR cameras with NIR Light Emission Diode: LED. EEG signals are suffred from noises while eye movement can be acquired without any influence from nise. Therefore, psychlogical status can be monitored with eye movement detection instead of EEG signal acquisition if there is relation between both. Through the experiments, it is found strong relation between both. In particular, relation between the number of rapid changes of line of sight directions and relatively high frequency components of EEG signals is found. It is also found that the number of rapid eye movement is counted when the users are reading the documents. The rapid eye movement is defined as 10 degrees of look angle difference for one second. Not only when the users change the lines in the document, but also when the users feel a difficulty for reading words in the document, the users' line of sight direction moves rapidly.
\end{abstract}

Keywords-EEG; eye movement; psychological status; alpha wave; beta wave

\section{INTRODUCTION}

Nowadays, the eye-based HCI has been widely used to assist not only handicap person but also for a normal person. In handicap person, especially paraplegic, they use eye-based $\mathrm{HCI}$ for helping them to self-sufficient in the daily life such as input text to compute [1], communication aids [2], controlling wheelchair [3], [4], fetch a meal on table using robot arm [5], etc. The eye key-in system has been developed by many researchers [1]. The commercial available system provided by Tobii Tracker Company has been used by many researchers for developing text input, customer interest estimator on the business market, etc. [6]. Technology has been successful in rehabilitating paraplegics' personal lives. Prof Stephen Hawking, who was diagnosed with Athe proposedotrophic Lateral Sclerosis (ALS), uses an electronic voice synthesizer to help him communicate with others [7]. By typing the text through aid of a predictive text entry system, approximating his voice, he is able to make coherent speech and present at conferences. To give another example, a paraplegic patient wearing a head-mounted camera is able to draw figures, lines, and play computer games [1]. Clearly, through the use of assistive technology, handicapped people are able to do feats on par with non-handicapped people.
The published papers discussing eye-based HCI system are categorized into: (1) vision-based and (2) bio-potential-based. The vision-based method utilized camera to capture an image and estimate the user sight. The key issue here is how the method/system could be deal with environment changing. Lighting changing, user movement, various types of user, etc have to cooperate with the system. The vision-based system could be explained as follow.

Eye mouse based on sight is developed [8]. The method searches and tracks the eye by using projection of difference left-right eye after it is success to detect the face. It obtains left and right direction that could be used for controlling mouse pointer without upward and downward directions. They implemented the method for controlling application such as "Block Escape" game and spelling program. Eye mouse by utilizing sight obtained from pupil location and detected by using Haar Classifier (OpenCv function) is developed [9]. It used blinking for replacing left click of mouse event. The system enabling it to control mouse by utilizing face movement and blinking is developed [10]. The Adaboost face detection method detects center position of face and tracks it by using Lucas-Kanade Optical flow. The user used the resulted location for controlling mouse cursor and will execute left mouse click by detecting the blinking. Human-computer interface by integrating eye and head position monitoring devices is developed [11]. It controlled the interface based on sight and blinking. The user command could be translated by system via sight and blinking. Also, they modified calibration method for reducing visual angle between the center of target and the intersection point (derived by sight). They reported that the modification allowed 108 or higher number of command blocks to be displayed on 14 inch monitor. Also, they reported that it has hit rate of $98 \%$ when viewed at the distance of $500 \mathrm{~mm}$. For triggering, the blinking invokes commands.

The bio-potential-based method estimated user behavior (eye behavior) by measuring user's bio-potential. The biopotential measurement instrument such as Electrooculograph (EOG), Electroencephalograph (EEG), etc could be used for measuring eye behaviors. The example of bio-potential-based has been applied in application of electric wheelchair controlled using EOG analyzed user eye movement via electrodes directly on the eye to obtain horizontal and vertical eye-muscle activity. 
Signal recognition analyzed Omni directional eye movement patterns [12]. I search pupil location on an eye image by using the proposed method that has been published [13]. I estimate the sight by converting the obtained position of pupil to sight angle. After the sight angle is estimated, I control the mouse cursor by using this sight.

In the following section, eye movement detection method is described followed by psychological status monitoring with EEG sensor. Then relations between eye movement and psychological status are described followed by conclusion with discussions.

\section{EYE MOVEMENT DETECTION SYSTEM}

\section{A. Hardware Configuration}

The system utilizes Infrared Camera NetCowBoy DC NCR-131 to acquire user image. I modified the position of 8 IR LED for adjusting illumination and obtaining stable image even illumination of environment changes as shown in Fig. 1.

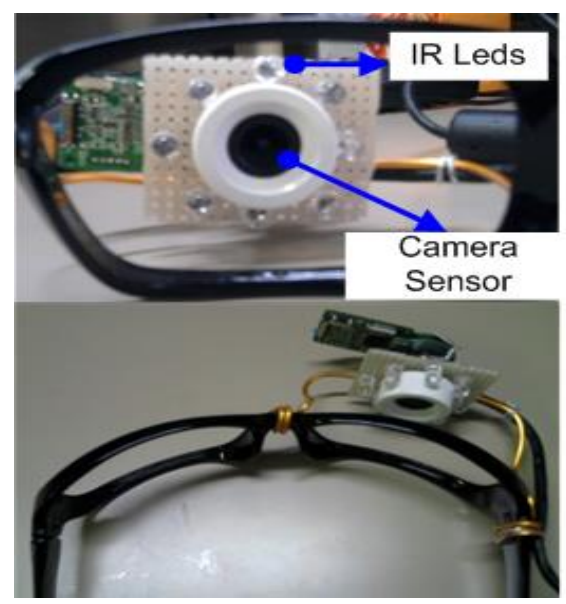

Fig. 1. Modified Camera Sensor

The use of IR camera will solve problem of illumination changes. I put the camera on user's glasses. Distance between camera and eye is $2 \mathrm{~cm}$. I use Netbook Asus Eee PC $1002 \mathrm{HA}$ with Intel Atom N270 CPU (1.6 GHz), 1GB Memory, 160 GB SATA HDD, and have small screen display 10 inch as main processing device. The software is developed under $\mathrm{C}++$ language of Visual Studio 2005 and OpenCv, image processing library, which can be downloaded as free at their website. The hardware configuration is shown in Fig.2.

\section{B. Eye Detection}

The eye detection is handled by adaptive thresholds and pupil knowledge. I do not need the tracking method because the camera is on the user's glasses, so the next eye location has the same position as the previous one. Pupil location is detected by using pupil knowledge such as color, size, shape, sequential location, and movement.

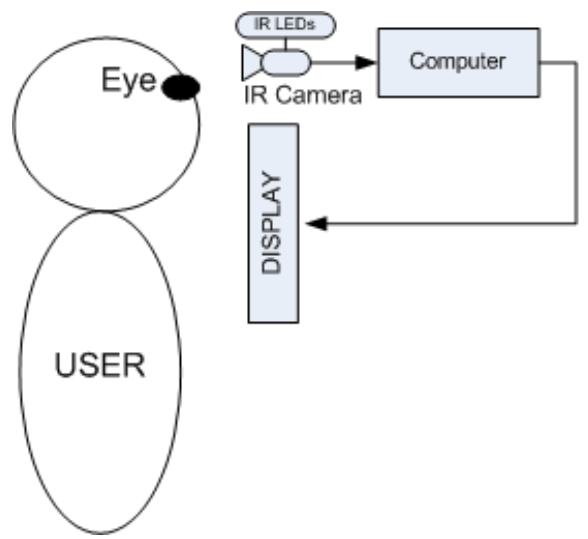

Fig. 2. Hardware Configuration

In pupil detection, pupil location is estimated as stated earlier using pupil knowledge extracted using an adaptive threshold to separate the pupil from other eye components. The threshold value $T$ is $0.27 \%$ below the mean $\mu$ of eye image $I$ and is derived from adjusting illumination intensity of 150 lux. The proposed threshold is suitable only for this condition but enables the camera to automatically adjust illumination as it changes.

$\mu=\frac{1}{N} \sum_{i=0}^{N-1} I_{i}$

$T=0.27 \mu$

Output from the adaptive threshold is black pixels representing the pupil in the image. To eliminate noise, I use a median filter. Widely adaptive threshold output is divided into three categories: (1) case 1 , in which noise free black pixels clearly represent the pupil, (2) case 2 , in which noise appears and is the same size and shape as pupil, and (3) case 3, when no pupil properties can be used to locate pupil. Cases are shown in Fig. 3.

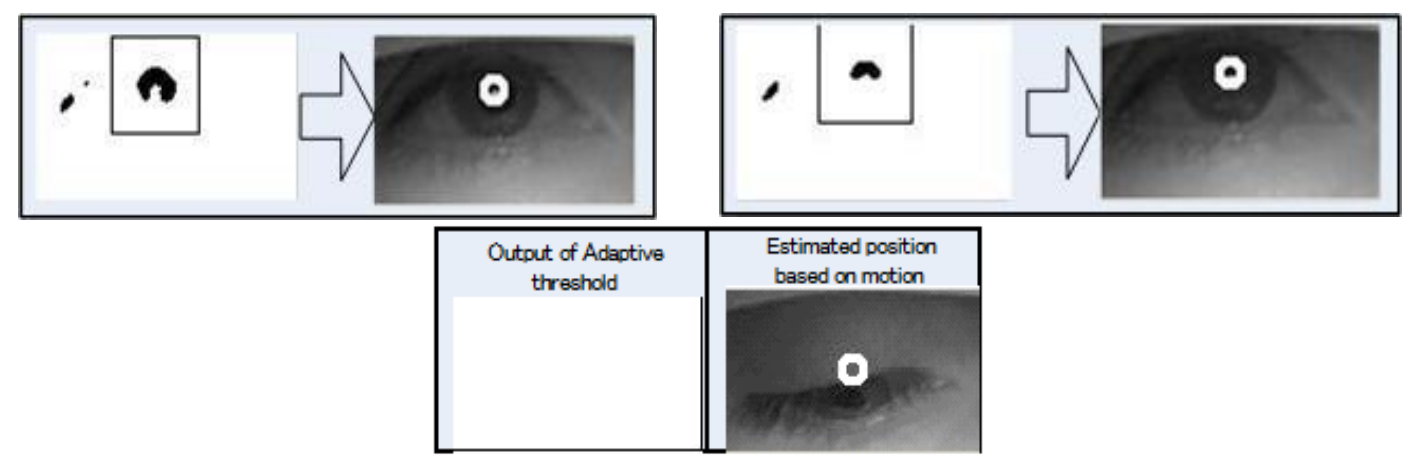

Fig. 3. Three cases in pupil detection that to be solved by using pupil knowledge 
Once adaptive threshold output is classified, I estimate pupil location in three steps based on pupil knowledge. In case 1 , the pupil is easily located by shape and size, even with noise in the image. In case 2, noise appears as almost the same size and shape as the pupil, e.g., when the adaptive threshold cannot be separated from other eye components such as the eyelid or the corner of the eye. To minimize these problems I recorded pupil movement histories assuming that the true pupil is closest to its previous location.

$$
P(t-1)-C<P(t)<P(t-1)+C
$$

Reasonable pupil location $P(t)$ is within the surrounding of previous location $P(t-1)$ with area $C$. In case 3 , when features cannot be found to locate the pupil as when the user is looking from the corner of the eye, I estimate pupil location based on the movement.

\section{EEG Sensor}

The EEG sensor used for getting EEG signal from users' forehead in the experiment is Brain Catcher BCG-1S manufactured by TECHNOS Co. Ltd. Outlook of the sensor is shown in Fig.4. The sensor consists of two subsystems, EEG sensor and EEG signal receiver. Major specification is shown in Table 1.

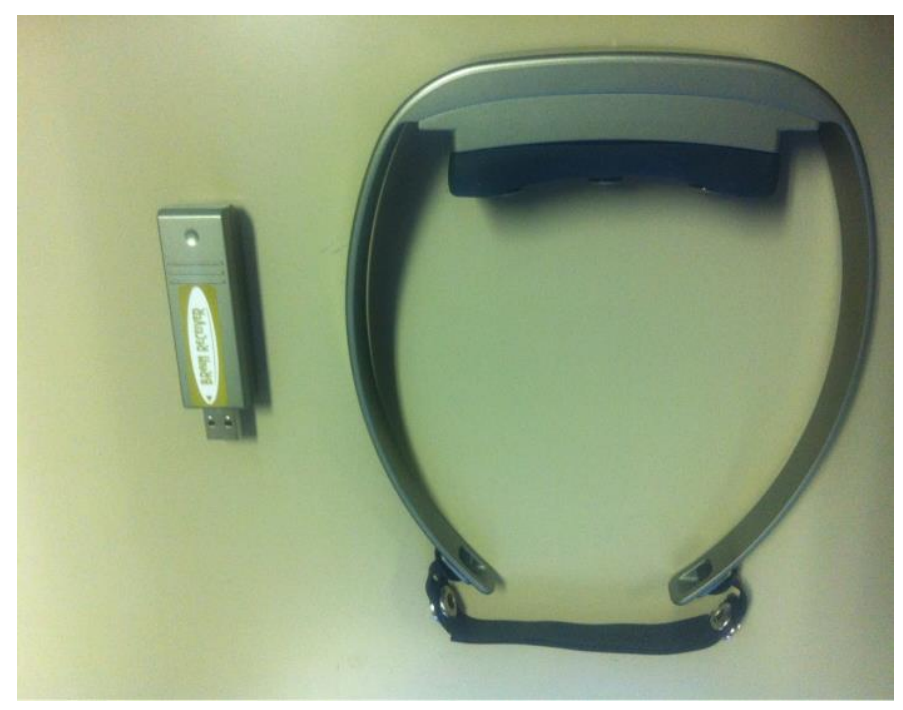

Fig. 4. Outlook of the EEG sensor used

TABLE I. SPECIFICATION OF BRAIN CATCHER BCG-1S MANUFACTURED BY TECHNOS CO. LTD.

\begin{tabular}{|c|c|}
\hline Size & W:23 $\times$ D:79 $\times$ H: $15(\mathrm{~mm})$ \\
\hline Weight & $16 \mathrm{~g}$ \\
\hline
\end{tabular}

(a)EEG signal receiver (USB terminal)

\begin{tabular}{|c|c|}
\hline Size & W: $160 \times \mathrm{D}: 180 \times \mathrm{H}: 37(\mathrm{~mm})$ \\
\hline Weight & $85 \mathrm{~g}$ \\
\hline
\end{tabular}

(b)EEG sensor

\section{EXPERIMENTS}

\section{A. Eye detection Accuracy}

In order to measure performance of pupil detection, I involved five different users who have different race and nationality (Indonesian, Japanese, Sri Lankan, and Vietnamese). The uses of many samples will prove that the proposed method work when it is used for all types of users. The eye movement data was collected from each user while was making several eye movement.

Eye images of three Indonesian show that even though images were taken from same country, each person has different eye shape. The number of one of the Indonesian images 882 samples. One of them has slated eye and the other two Indonesians have narrow eye and clear pupil. The number of samples of these two Indonesian is 552 and 668, respectively. The collected data from Sri Lankan consists of the number of images is 828 samples. His skin color is black and eyelid is thick. Collected data from Japanese consists of the number of images is 665 samples. His skin color is bright and eye is slant. The collected data from Vietnamese is almost same of the other five.

This experiment evaluates pupil detection accuracy and variance against different user by counting the success sample and the fail one. After accuracy of pupil detection has been counted, I compared the proposed method with adaptive threshold method and also template matching method. The compared adaptive threshold method uses combination between adaptive threshold itself and connected labeling method. Also, another compared method uses pupil template as reference and matched with the pupil images. The accuracy of the proposed pupil detection method against different users is shown in TABLE II. . The result data show that the proposed pupil detection method is accurate and robust against different users with variance value is 16.27.

TABLE II. ACCURACY OF THE PROPOSED PUPIL DETECTION METHOD AGAINST DifFERENT USERS, THIS TABLE SHOWS THAT THE PROPOSED METHOD IS RoBUSt AGAINST DIFFERENT USER AND ACCURATE

\begin{tabular}{|l|l|l|l|l|}
\hline $\begin{array}{l}\text { User } \\
\text { Types }\end{array}$ & Nationality & $\begin{array}{l}\text { Adaptive } \\
\text { Threshold }(\%)\end{array}$ & $\begin{array}{l}\text { Template } \\
\text { Matching }(\%)\end{array}$ & $\begin{array}{l}\text { Proposed } \\
\text { Method (\%) }\end{array}$ \\
\hline 1 & Indonesian & 99.85 & 63.04 & 99.99 \\
\hline 2 & Indonesian & 80.24 & 76.95 & 96.41 \\
\hline 3 & Sri Lankan & 87.8 & 52.17 & 96.01 \\
\hline 4 & Indonesian & 96.26 & 74.49 & 99.77 \\
\hline 5 & Japanese & 83.49 & 89.1 & 89.25 \\
\hline 6 & Vietnamese & 98.77 & 64.74 & 98.95 \\
\hline Average & & 91.07 & 70.08 & 96.73 \\
\hline \multicolumn{2}{|l|}{ Variance } & 69.75 & 165.38 & 16.27 \\
\hline
\end{tabular}

Line of sight direction is detected with NIR camera and NIR LED. Therefore, eye color and skin color are not matter for the eye movement detections. 


\section{B. Relation between Eye Movements and EEG Signals}

Four Japanese users are selected for the experiment of eye movement detections and EEG signal acquisitions. Through the experiment, two documents (simple document ${ }^{1}$ and complicated document ${ }^{2}$ which are shown in Fig.5) are read by the users. It is expected that brain is in very active for the complicated document while users are in relax status for the simple document.

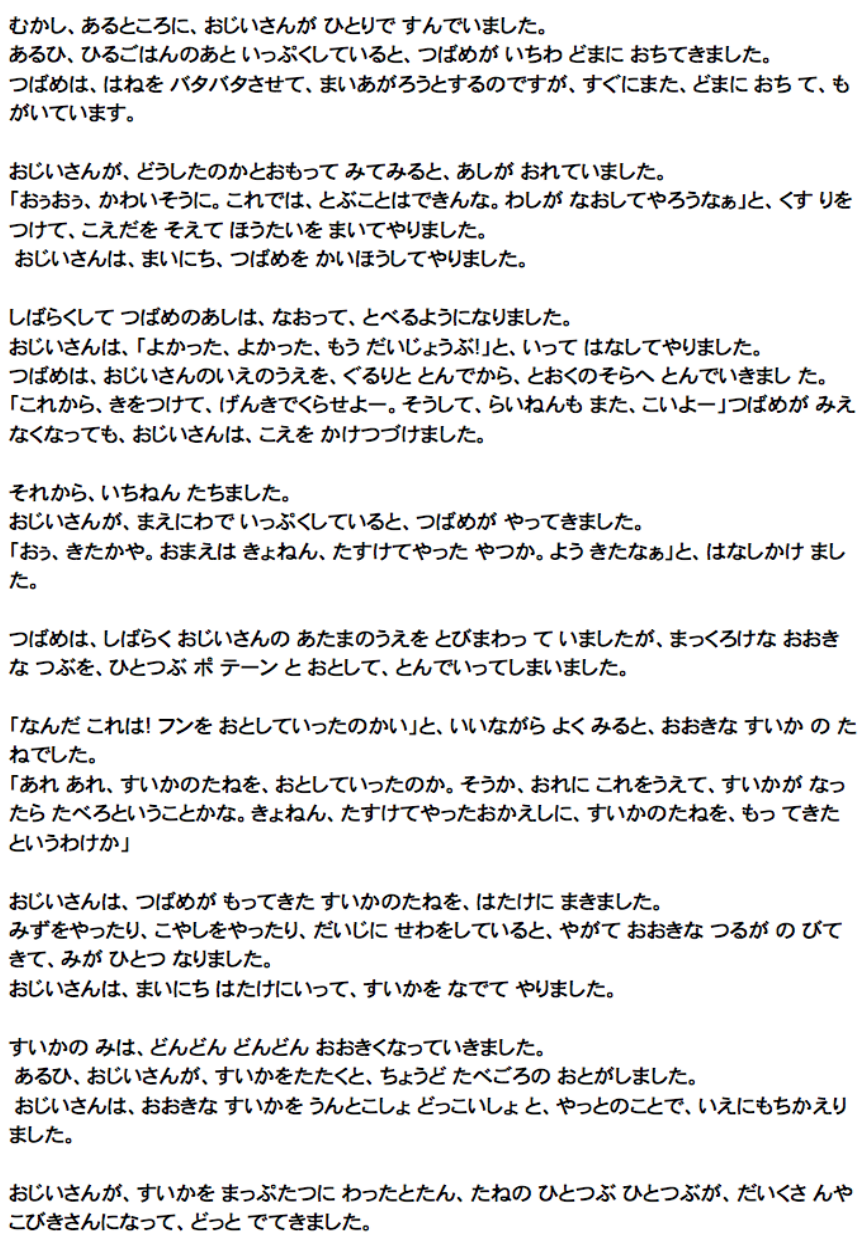

(a)Simple document
脳波（のうは、Electroencephalogram：EEG）は、ヒト・動物の脳から生じる電気 活動を、頭皮上、蝶形骨底、鼓膜、脳表、脳深部などに置いた電極で記録したもの である。

英語のElectroencephalogramの忠実な訳語として、脳電図、EEGという呼び方もあ

り、中国語ではこちらの表現法を取っている。

本来は、脳波図と呼ぶべきであるが、一般的には「脳波」と簡略化して呼ばれるこ とが多い。

脳波を測定、記録する装置を脳波計(Electroencephalograph：EEG)と呼び、それを 用いた脳波検查(Electroencephalography：EEG)は、医療での臨床検査として、また 医学、生理学、心理学、工学領域での研究方法として用いられる。

検査方法、検査機械、検査結果のどれも略語はEEGとなるので、使い分けに注意が 必要である。

個々の神経細胞の発火を観察する単一細胞電極とは異なり、電極近傍あるいは遠隔 部の神経細胞集団の電気活動の総和を観察する（少数の例外を除く）。 近縁のものに、神経細胞の電気活動に伴って生じる磁場を観察する脳磁図（のうじ ず、Magnetoencephalogram : MEG) がある。 直接記録する方法はしばしば臨床検査として用いられる。背景脳波（基礎律動）や 突発活動（てんかん波形など）を観察する。

各種のてんかん、ナルコレプシー、変性疾患、代謝性疾患、神経系の感染症、脳器 質的疾患、意識障害、睡眠障害、精神疾患などの診断の補助・状態把握などに用い られる。 波形の加工の方法として、主なものに加算平均法、双極子推定法、周波数解析、コ ヒーレンス法、主成分分析、独立成分分析などがあり、一部は臨床でも用いられてい る。

脳波を直接記録する方法はしばしば臨床検査として用いられる。背景脳波（基礎律 動）や突発活動（てんかん波形など）を観察する。

各種のてんかん、ナルコレプシー、変性疾患、代謝性疾患、神経系の感染症、脳器 質的疾患、意識障害、睡眠障害、精神疾患などの診断の補助・状態把握などに用い られる。

波形の加工の方法として、主なものに加算平均法、双極子推定法、周波数解析、コ ヒーレンス法、主成分分析、独立成分分析などがあり、一部は臨床でも用いられてい る。

\section{(b)Complicated document}

Fig. 5. Documents used for the experiment

Fig.6 shows EEG signals when the users read the simple document.

Superimposed EEG signals for four users are shown in Fig.7 (The simple document).

Meanwhile, Fig.8 shows those when the users read the complicated document.

\footnotetext{
${ }^{1}$ Simple document in Japanese is written in "Hiragana" character only. The content of the document is story for children. Therefore, it is very easy to read. ${ }^{2}$ Complicated document in Japanese is written in "Kanji" and "Hiragana" characters. The content of the document is text book for psychology for university students. Therefore, it is rather difficult to read.
} 


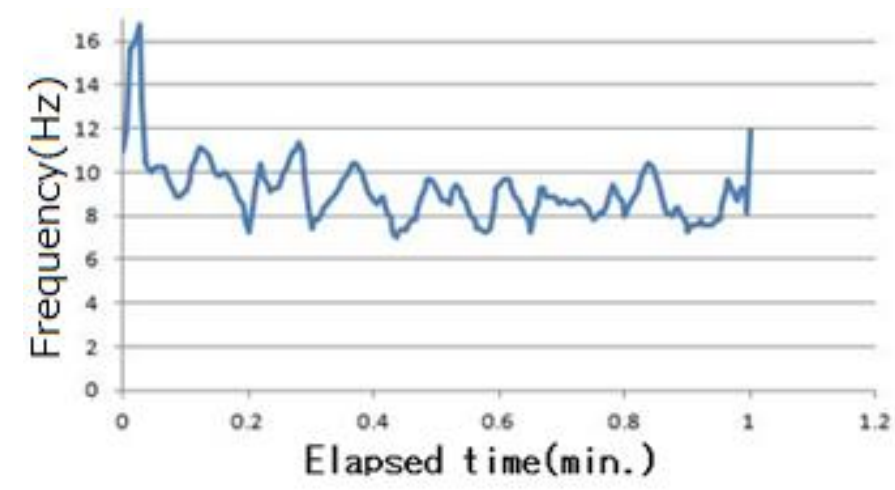

(a)A user
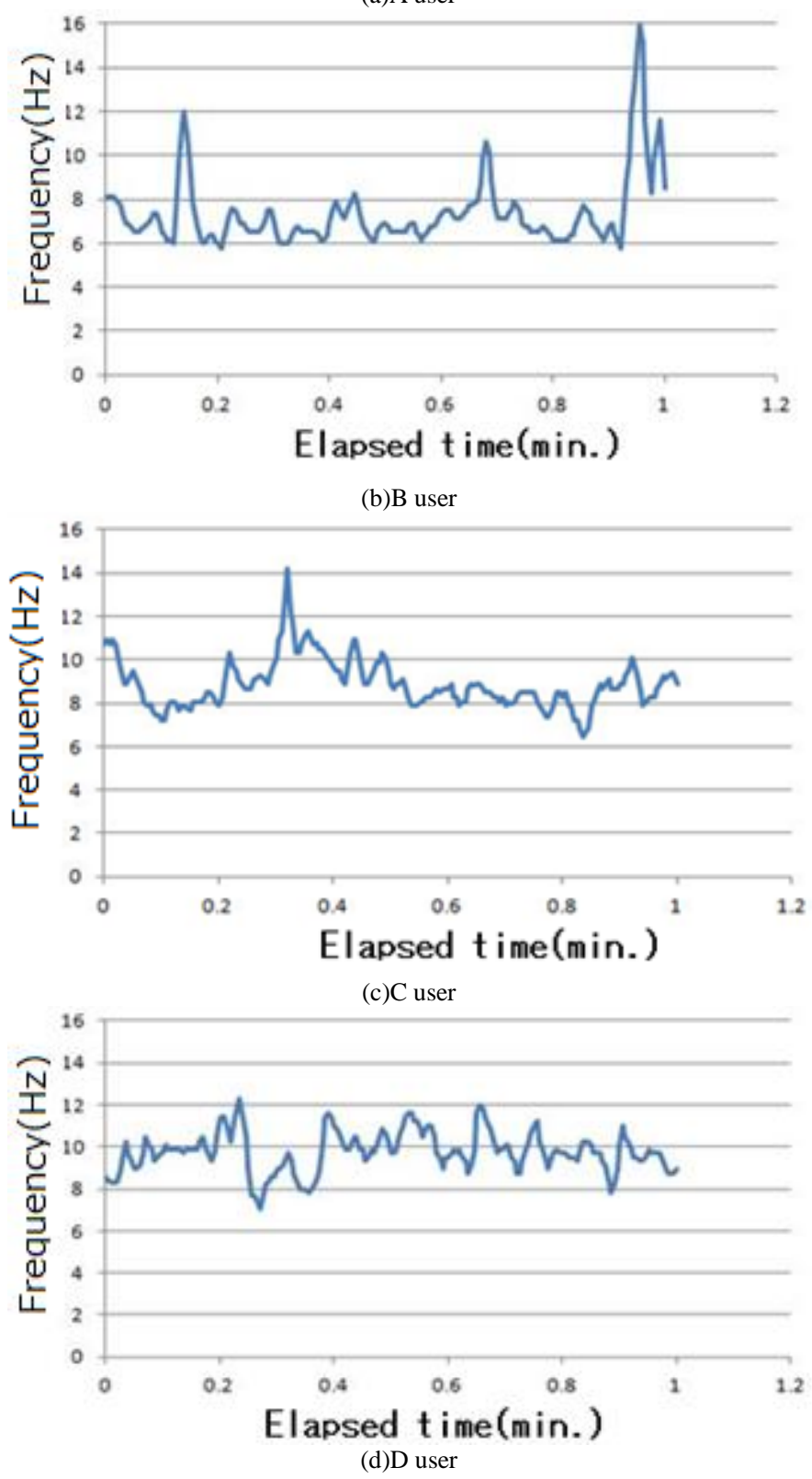

Fig. 6. EEG signals when the users read the simple document

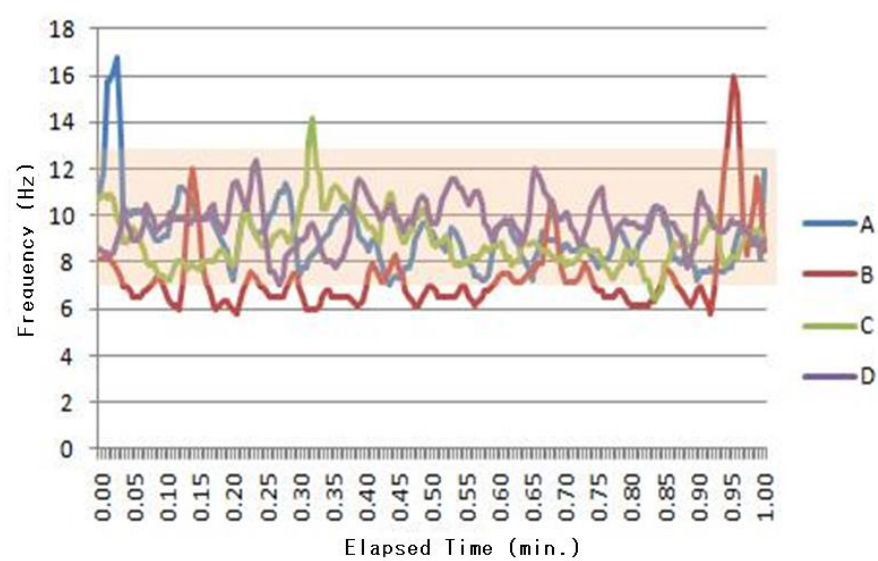

Fig. 7. Superimposed EEG signals for four users (The simple document)

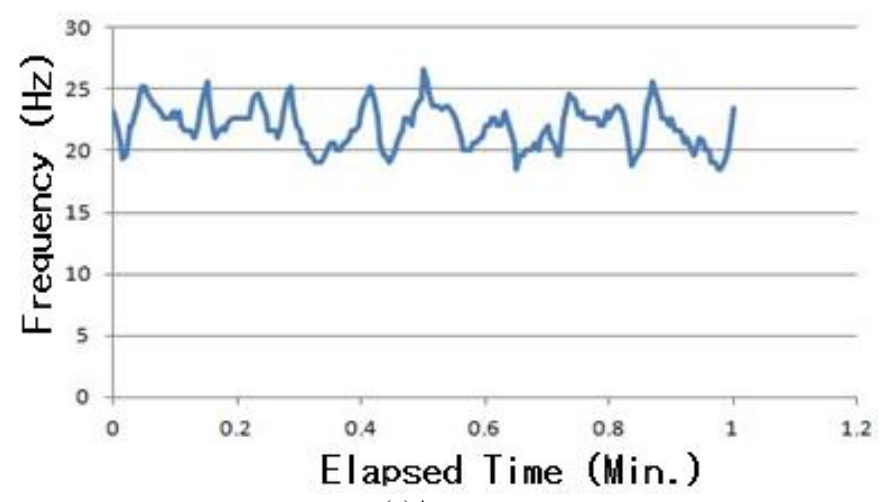

(a)A user

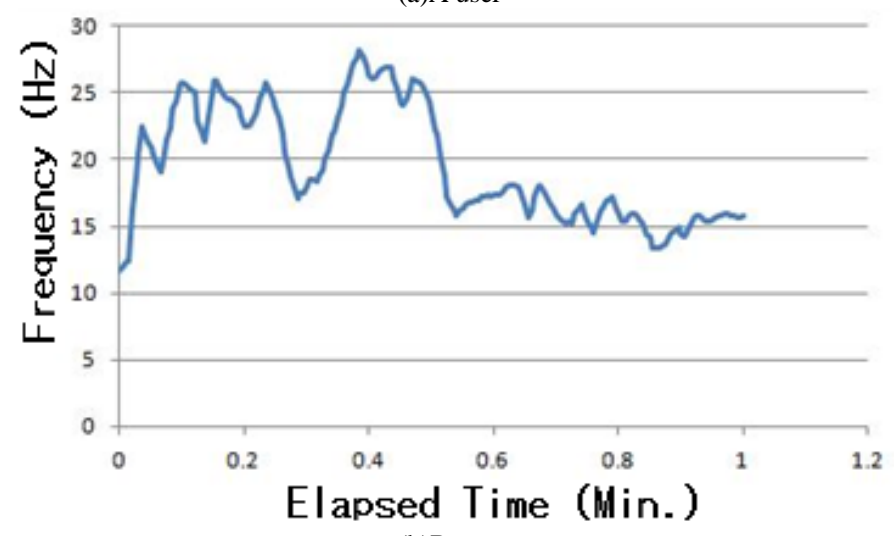

(b)B user

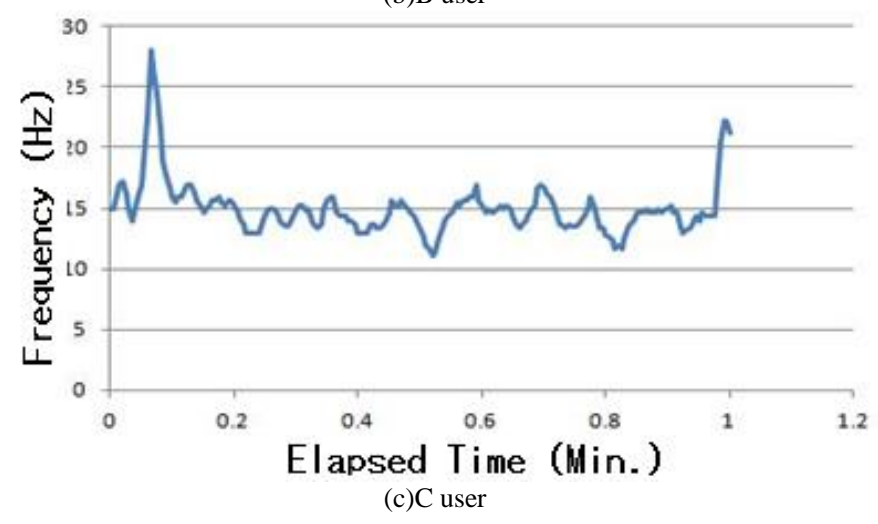




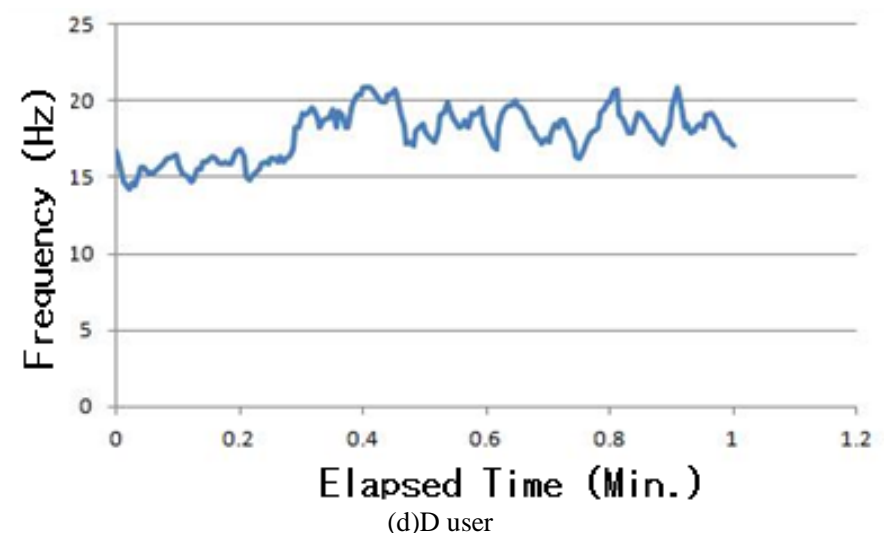

Fig. 8. EEG signals when the users read the complicated document

Superimposed EEG signals for four users are shown in Fig.9 (The complicated document).

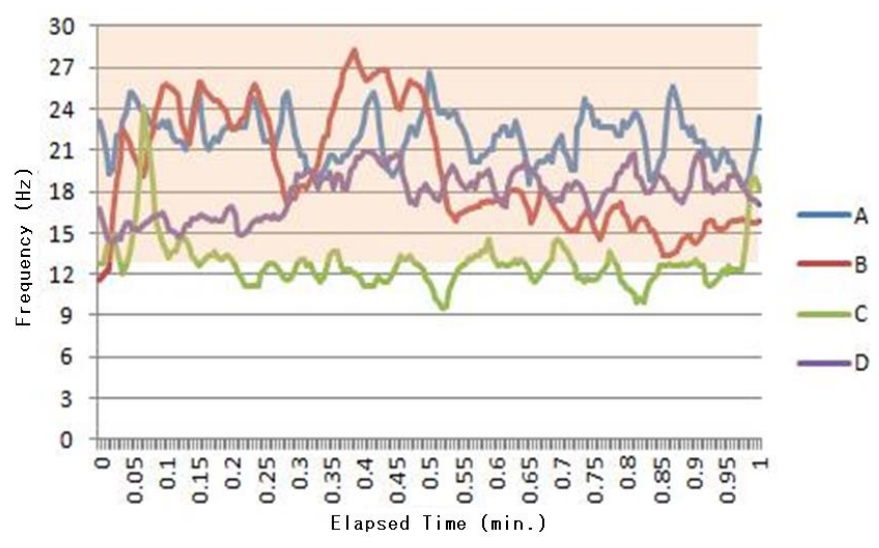

Fig. 9. Superimposed EEG signals for four users (The complicated document)

It is found that the frequency components for the simple document are much lower than those for the complicated document through a comparison between Fig.7 and Fig.9. The time variation is not so large. Also, there is not so large discrepancy among four users except user $\mathrm{C}$. The user $\mathrm{C}$ is good at reading documents and has a plenty of knowledge and experiences on the contents of the documents.

From time to time, frequency component is getting high when users are reading complicated portions of the documents while is getting down when users are reading simple portions of the documents as shown in Fig.7 and Fig.9.

On the other hand, the number of rapid eye movement is counted when the users are reading the documents. The rapid eye movement is defined as 10 degrees of look angle difference for one second. Not only when the users change the lines in the document, but also when the users feel a difficulty for reading words in the document, the users' look direction moves rapidly. The number of the rapid eye movements is shown in Fig.10. The timing of the rapid eye movements is synchronized to raising the EEG frequency component. Namely, when the users feel a difficulty of reading the documents and line changes of the documents, EEG frequency components are raising and eye moves rapidly as shown in Fig.11 (Red circle indicates such moments).

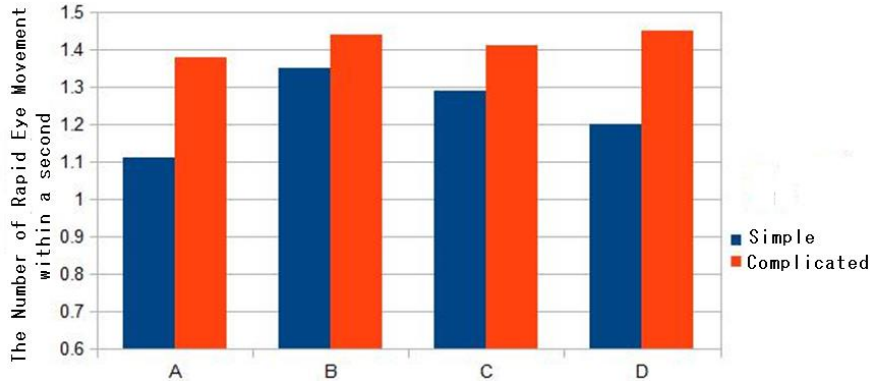

Fig. 10. The number of rapid eye movements

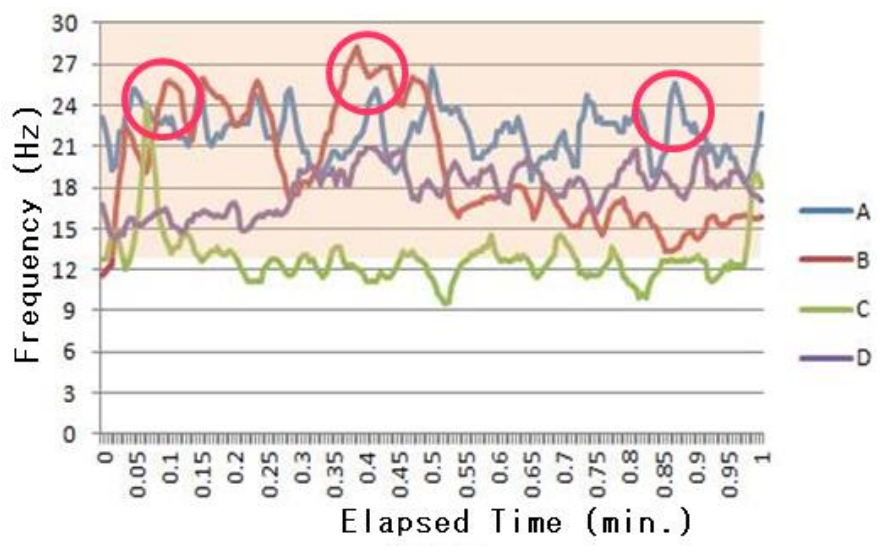

Fig. 11. EEG frequency components are raised when look direction changes rapidly

\section{CONCLUSION}

Relations between psychological status and eye movements are found through experiments with readings of different types of documents as well as playing games. Psychological status can be monitored with Electroencephalogram: EEG sensor while eye movements can be monitored with Near Infrared: NIR cameras with NIR Light Emission Diode: LED. It is found that strong relation between both. In particular, the number of rapid changes of looking directions and relatively high frequency components of EEG signals. Therefore, it is possible to detect psychological status with monitoring eye movements. Due to the fact that EEG signals used to be affected by surrounding noises, eye movement detection is much useful for psychological status monitoring instead of EEG signals.

It is found that the number of rapid eye movement is counted when the users are reading the documents. The rapid eye movement is defined as 10 degrees of look angle difference for one second. Not only when the users change the lines in the document, but also when the users feel a difficulty for reading words in the document, the users' look direction moves rapidly. It is also found that the timing of the rapid eye movements is synchronized to raising the EEG frequency component. Namely, when the users feel a difficulty of reading the documents and line changes of the documents, EEG frequency components are raising and eye moves rapidly.

Future research works are required for typical psychological status monitoring, hatred, beloved, joy, anger, happy, surprise etc. with eye movement detection. Then the patients without mimic muscle function can represent their 
emotions. Also, psychological status monitored with the proposed eye movement detection is useful for triage of victims when they evacuate from disaster occurred areas to safe areas. Because vital sign which consist heart rate, blood pressure, the number of breath, body temperature and copiousness is required for triage. If patients in hospitals, group homes, etc. wear the glass with eye movement detection function and physical status monitoring sensor and network system for transmission of these data, then the patients can be saved their life because their status are known together with their location and attitude.

\section{ACKNOWLEDGMENT}

The author would like to thank Dr. Ronny Mardiyanto for his effort to the experiment on eye detection accuracy evaluation.

\section{REFERENCES}

[1] EYEWRITER: low-cost, open-source eye-based drawing system. Disponivel em: <http://www. crunchgear.com/2009/08/25/\%20eyewriter-low-cost-\%20open-sourceeye-\%20based-drawing-system/>. Acesso em: 7 October 2011.

[2] LEFF, R. B.; LEFF, A. N. 4.954.083, 1990.

[3] ARAI, K.; MARDIYANTO, R. A Prototype of ElectricWheelchair Controlled by Eye-Only for Paralyzed User. Journal of Robotic and Mechatronic, p. 66-74, 2011.

[4] DJOKO PURWANTO, R. M. A. K. A. Electric wheel chair control with gaze detection and eye blinking. Artificial Life and Robotics, AROB Journal. 2009. p. 397-400.

[5] ARAI, K.; YAJIMA, K. Robot Arm Utilized Having Meal Support System Based on Computer Input by Human Eyes Only. International Journal of Human Computer Interaction (IJHCI), p. 1-9, 2011

[6] JOHN J, M. et al. EyeKeys: A Real-Time Vision Interface Based on Gaze Detection from a Low-Grade Video Camera. 2004 Conference on Computer Vision and Pattern Recognition Workshop. 2004. p. 159.
[7] ARAI, K.; YAJIMA, K. Robot Arm Utilized Having Meal Support System Based on Computer Input by Human Eyes Only. International Journal of Human Computer Interaction (IJHCI), p. 1-9, 2011

[8] JOHN J, M. et al. EyeKeys: A Real-Time Vision Interface Based on Gaze Detection from a Low-Grade Video Camera. 2004 Conference on Computer Vision and Pattern Recognition Workshop. 2004. p. 159.

[9] CHANGZHENG, L.; CHUNG-KYUE, K.; JONG-SEUNG, P. The Indirect Keyboard Control System by Using the Gaze Tracing Based on Haar Classifier in OpenCV. 2009 International Forum on Information Technology and Applications.. 2009. p. 362-366.

[10] ZHU, H.; QIANWEI, L. Vision-Based Interface: Using Face and Eye Blinking Tracking with Camera. 2008 Second International Symposium on Intelligent Information Technology Application. 2008. p. 306-310.

[11] PARK K.S., L. K. T. Eye-controlled human/computer interface using the line-of-sight and the intentional blink. Computers and Industrial Engineering. 1993. p. 463-473.

[12] BAREA, R. et al. System for Assisted Mobility using Eye Movements based on Electrooculography. IEEE Transaction on Neural System and Rehabilitation Engineering, v. 10, p. 209-218, 2002.

[13] ARAI, K.; MARDIYANTO, R. Improvement of gaze estimation robustness using pupil knowledge. Proceedings of the International Conference on Computational Science and Its Applications (ICCSA2010). 2010. p. 336-350.

\section{AUTHORS PROFILE}

Kohei Arai, He received BS, MS and PhD degrees in 1972, 1974 and 1982, respectively. He was with The Institute for Industrial Science, and Technology of the University of Tokyo from 1974 to 1978 also was with National Space Development Agency of Japan (current JAXA) from 1979 to 1990. During from 1985 to 1987 , he was with Canada Centre for Remote Sensing as a Post Doctoral Fellow of National Science and Engineering Research Council of Canada. He was appointed professor at Department of Information Science, Saga University in 1990. He was appointed councilor for the Aeronautics and Space related to the Technology Committee of the Ministry of Science and Technology during from 1998 to 2000. He was also appointed councilor of Saga University from 2002 and 2003 followed by an executive councilor of the Remote Sensing Society of Japan for 2003 to 2005. $\mathrm{He}$ is an adjunct professor of University of Arizona, USA since 1998. He also was appointed vice chairman of the Commission "A" of ICSU/COSPAR in 2008. He wrote 30 books and published 500 journal papers 